Aim of the study: To perform a systematic review and formal meta-analysis of the literature reporting on HPV detection in bronchial squamous cell papillomas (SCP).

Material and methods: The literature was searched up to June 2012. The effect size was calculated as event rate $(95 \% \mathrm{Cl})$, with homogeneity testing using Cochran's $Q$ and $\mathrm{I}^{2}$ statistics. Meta-regression was used to test the impact of studylevel covariates (HPV detection method, geographic origin) on effect size, and potential publication bias was estimated using funnel plot symmetry.

Results: Fifteen studies were eligible, covering 89 bronchial SCPs from different geographic regions. Altogether, 38 (42.7\%) cases tested HPV-positive; effect size 0.422 (95\% Cl: 0.311-0.542; fixed effects model), and $0.495(95 \% \mathrm{Cl}$ : $0.316-0.675$; random effects model). In meta-analysis stratified by i) HPV detection technique and ii) geographic study origin, the between-study heterogeneity was not significant for either; $p=$ $=0.348$, and $p=0.792$, respectively. In maximum likelihood meta-regression, HPV detection method $(p=0.150)$ and geographic origin of the study $(p=0.164)$ were not significant study-level covariates. Some evidence for publication bias was found only among in situ hybridization (ISH)-based studies and among studies from Europe, but with a negligible effect on summary effect size estimates. In sensitivity analysis, the metaanalytic results were robust to all oneby-one study removals.

Conclusions: In formal meta-regression, the variability in HPV detection rates reported in bronchial SCPS is not explained by the HPV detection method or geographic origin of the study.

Key words: bronchial papilloma, solitary, squamous cell, HPV, meta-analysis, meta-regression, study heterogeneity, publication bias, detection method.

Contemp Oncol (Pozn) 2013; 17 (5): 427-434 DOI: $10.5114 /$ wo.2013.38565

\section{Solitary bronchial squamous cell papilloma - another human papillomavirus (HPV)-associated benign tumor: systematic review and meta-analysis}

\author{
Kari Syrjänen ${ }^{12}$, Stina Syrjänen ${ }^{3}$
}

1Department of Oncology \& Radiotherapy, Turku University Hospital, Turku, Finland 2Barretos Cancer Hospital, Teaching and Research Institute, Barretos - SP, Brazil ${ }^{3}$ Department of Oral Pathology and Radiology, Institute of Dentistry, University of Turku, Turku, Finland

\section{Introduction}

The first reports on solitary bronchial squamous cell papilloma (SCP) appeared in 1954, when three authors provided descriptions of this new entity [1-3]. It was soon recognized that bronchial SCP can also appear as multiple lesions called (tracheo)bronchial papillomatosis [4, 5]. Until the mid 1980s solitary bronchial SCP was regarded as an extreme rarity [5, 6]. When first reviewed in 1985, Maxwell et al. could collect only 11 such cases in the English literature [7]. As emphasized before [8], however, this number is a clear underestimate, because in addition to the cases included in their review [5-7, 9-13], a large number of bronchial SCPs had been reported, but mostly in non-English literature [14-53]. Interestingly, this same trend seems to continue in more recent reports [54-75]. According to our best estimates, the total number of bronchial SCPs (and papillomatosis) reported by now reaches several hundred cases [8].

Bronchial SCP must be considered a rare disease, and no estimates are available on their incidence rates [8]. There are two peculiar features in the clinical history of these lesions: i) a tendency to spread to multiple sites within the bronchial tree $[4,10,14,19,25,30,32,34,43,47,48,52,63,75]$, and ii) a substantial potential for malignant transformation $[2,8,11,27,39,40,50$, $51,57,58,66,71]$. These two characteristics strongly implicate an infectious etiology of bronchial SCPS. Indeed, their clinical behavior closely resembles that of recurrent respiratory papillomatosis (RRP) [8], and natural history of sinonasal papillomas.

While the etiologic role of human papillomavirus (HPV) in RRP is well established [8], the possible involvement of this virus in sinonasal papillomas was first suggested by us in 1983 [76], based on detection of HPV antigen expression in a single papilloma. This was soon confirmed by demonstration of HPV DNA in a series of cases [77], and HPV involvement in sinonasal papillomas is well established at present [78].

The first clue on possible HPV involvement in bronchial SCPs was provided by two cytological reports from 1975 and 1979, when Roglic et al. [79] and Rubel et al. [80], respectively, described characteristic cytopathic changes of HPV (i.e., koilocytosis) in the sputum samples, thus emphasizing their similarity to genital HPV lesions (condyloma). This coincides with the observations of us, who in 1979 were the first to describe similar evidence in malignant bronchial squamous cell neoplasia [81, 82]. However, it took almost a decade until Trillo and Guha (in 1988) first demonstrated HPV antigens and identified 
HPV particles in two bronchial SCPs [83]. The interest in bronchial SCP as a potential HPV-associated benign tumor increased slowly throughout the 1990s [8]. When first reviewed in 2002, the literature reporting HPV detection in bronchial SCPs included 9 studies covering 61 SCP cases, of which 29 (47.5\%) tested HPV-positive [84].

With the widespread implementation of prophylactic HPV vaccines, it has become increasingly important to estimate the total disease burden (in addition to genital lesions) potentially preventable by the current and new generation HPV vaccines $[85,86]$. To cast further light on the controversial role of HPV in bronchial SCP, it was felt appropriate to conduct a systematic review and formal meta-analysis, covering all the published literature without any restrictions to the HPV detection methods or geographic origin of the study.

\section{Material and methods}

\section{Data abstraction}

We identified eligible studies by searching MEDLINE (via PubMed) and reference lists from original articles, book chapters and other reviews until June 2012. No language or dateof-publication limitations were imposed. The search terms included: papillomavirus, HPV, papilloma, solitary, squamous cell, bronchus, bronchial, papillomatosis, malignant transformation. We considered all publications appearing in peer-reviewed journals eligible, irrespective of which method (see later) was used for HPV detection, provided that the report included exact numbers of analyzed cases and those testing HPV-positive, necessary for calculation of the event rates (= HPV prevalence) and their 95\% confidence intervals (95\% Cl).

Altogether, $>400$ abstracts were derived from the database, covering the years 1954 to 2012. For the present metaanalysis, a total of 15 original studies were determined eligible, all including cases of bronchial papillomas analyzed for HPV detection. Because they were included in a recent metaanalysis, all studies reporting only bronchial carcinomas were excluded from this meta-analysis.

From the summaries and/or body texts of each eligible study, we abstracted the following information: HPV detection method, geographic region of the study, HPV genotypes analyzed and/or detected, total number of cases analyzed, number testing HPV-positive, per cent HPV-positivity, authors, and publication year. Only the studies reporting HPV in solitary bronchial papillomas or cases of bronchial papillomatosis were included, whereas all studies describing tracheobronchial spread of RRP and/or their malignant conversion were excluded.

\section{Statistical analyses}

The specific software Comprehensive Meta Analysis ${ }^{\mathrm{TM}}$ (Version 2.2.064; Biostat Inc., Englewood, NJ, USA) was used to perform the meta-analysis. The software calculates the event rates (logit event rates, SE and variance) based on the events and sample size data. To assess overall heterogeneity in the event rates between the different studies, Cochran's Q (twosided) homogeneity $p$ value as well as $1^{2}$ statistics (for percentage of variation) were used [87]. To evaluate the possible publication bias, funnel plots were drawn by plotting the logit event rates by their precision (1/SE) [88]. Funnel plots were evaluated for asymmetry using the following statistics: i) Begg and Mazumdar rank correlation [89], ii) Egger's test of the intercept (regression) [90], and iii) Duval and Tweedie's "trim and fill" method [91], which imputes the results that are hypothetically missing due to the publication bias.

To assess the variation in the event rates (i.e., HPV prevalence) due to the differences between the individual studies, we evaluated the study characteristics using stratified random-effects meta-analysis and restricted maximum likelihood meta-regression. Stratified meta-analysis allows descriptive comparison of the summary event rates across the different categories of specified study characteristics. Restricted maximum likelihood meta-regression formally compares these differences in event rates across the selected study-level covariates and estimates the among-study variance [92]. Given the inherent differences in analytical sensitivities between the different HPV detection methods - immunohistochemistry (IHC), in situ hybridization (ISH), and polymerase chain reaction (PCR) - meta-analyses were performed across these strata. Similarly, to distinguish true study-specific effects from random variation, all analyses were also stratified by the geographic regions of their origin, blamed as one of the reasons for variability in HPV prevalence [8, 45]. HPV detection method and geographic study origin were also tested as study-level covariates in formal meta-regression.

Sensitivity analysis was performed to assess the influence of each individual study on the strength and stability of the meta-analytic results. Sensitivity analysis runs the analysis $\mathrm{k}(n=14)$ times, each time removing one study to show that study's impact on the combined effect size. The sensitivity of the results to these one-by-one study removals was evaluated by descriptively comparing the magnitude and precision of the random-effects summary event rates (point estimates).

\section{Results}

\section{Eligible studies}

A total of 15 studies were considered eligible for the present analysis [58, 70, 74, 83, 93-103], comprising 89 bronchial SCPs analyzed by different HPV detection methods. Included are both case reports and larger series, comprising up to 31 cases analyzed by PCR [98] and 15 papillomas examined by ISH [94] (Table 1). The methods used to evaluate the HPV involvement include the following: IHC [83], ISH [58, 70, 74, 93-97, 102], and PCR [98-101, 103]. Based on the available data on geographic regions with different HPV prevalence, the studies were categorized into the following regions of origin: Other Asia (China excluded), Europe, and North America. These 15 studies comprise the target of this meta-analysis. Of all analyzed 89 bronchial SCPs, 38 (42.7\%) tested HPV-positive.

\section{Analytical results}

\section{Point estimates of event rates}

The crude HPV-positivity (38/89) translates to event rates (i.e., effect size, summary HPV prevalence) of 0.422 ( $95 \%$ 
Table 1. Studies reporting on HPV detection in solitary bronchial squamous cell papillomas

\begin{tabular}{|c|c|c|c|c|c|c|c|}
\hline \multicolumn{2}{|c|}{ Method/histological type } & \multicolumn{6}{|c|}{ HPV positive } \\
\hline $\begin{array}{l}\text { Detection } \\
\text { method* }^{*}\end{array}$ & $\begin{array}{c}\text { Histological } \\
\text { type }\end{array}$ & $\begin{array}{c}\text { Area } \\
\text { or country }\end{array}$ & $\begin{array}{l}\text { HPV types } \\
\text { detected }\end{array}$ & $\begin{array}{c}\text { Number/ } \\
\text { total }\end{array}$ & $\%$ & Authors and year & Ref. No \\
\hline IHC, EM & SCP & Canada & - & $2 / 2$ & 100 & Trillo et al. 1988 & {$[83]$} \\
\hline ISH & SCP & USA & $6 / 11$ & $1 / 1$ & 100 & Kerley et al. 1989 & {$[93]$} \\
\hline ISH & SCP & France & 11 & $1 / 1$ & 100 & Bejui-Thivolet et al. 1990 & {$[58]$} \\
\hline ISH & SCP & UK & 16 & $1 / 15$ & 6.7 & Carey et al. 1990 & [94] \\
\hline ISH & SCP & Austria & $6 / 11$ & $6 / 6$ & 100 & Popper et al. 1992 & [95] \\
\hline $\mathrm{ISH}$ & SCP & USA & $6 / 11$ & $2 / 2$ & 100 & Yousem et al. 1992 & [96] \\
\hline ISH & SCP & USA & $6 / 11$ & $1 / 1$ & 100 & Katial et al. 1994 & {$[97]$} \\
\hline PCR, ISH & SCP & Austria & $6,11,16,18$ & $11 / 31$ & 35.5 & Popper et al. 1994 & {$[98]$} \\
\hline PCR, ISH & SCP & USA & $6,11,16,18$ & $5 / 14$ & 35.7 & Flieder et al. 1998 & [99] \\
\hline PCR & SCP & Japan & 11 & $1 / 1$ & 100 & Kawaguchi et al. 1999 & [100] \\
\hline PCR, ISH & SCP & Japan & 6,16 & $1 / 1$ & 100 & Harada et al. 2000 & [101] \\
\hline ISH & $\mathrm{SCP}$ & France & - & $0 / 1$ & 0.0 & Paganin et al. 2009 & {$[70]$} \\
\hline ISH, PCR & SCP & Japan & - & $0 / 1$ & 0.0 & Inamura et al. 2011 & {$[102]$} \\
\hline PCR & SCP & USA & - & $0 / 1$ & 0.0 & Lagana et al. 2011 & [103] \\
\hline $\mathrm{ISH}$ & SCP & USA & - & $1 / 3$ & 33.3 & Lang et al. 2011 & {$[74]$} \\
\hline
\end{tabular}

*Method listed first was used as the HPV detection method in meta-analysis database, EM - electron microscopy, IHC - immunohistochemistry, ISH - in situ hybridization, $P C R$ - polymerase chain reaction, SCP-squamous cell papilloma

Cl: 0.311-0.542), using the fixed effects (FE) model, and 0.495 (95\% Cl: 0.316-0.675), using the random effects (RE) model (Fig. 1). Table 2 depicts the meta-analytic results of those 15 studies, stratified by the HPV detection technique. There is significant heterogeneity only between the studies $(n=9)$ using ISH, as measured by Cochran's Q statistic, with $p=0.038$. This heterogeneity becomes of borderline significance in com- parison within strata $(p=0.056)$, and disappears in comparison between strata (random effects model, $p=0.348$ ). The percentage of variation $\left(\mathrm{I}^{2}\right)$ is higher $(50.9 \%)$ for ISH-based studies than among PCR studies (7.0\%). Using the RE model, studies based on ISH give higher point estimates of HPV prevalence (0.534, i.e. $53.4 \%)$, as compared with PCR studies (39.1\%).

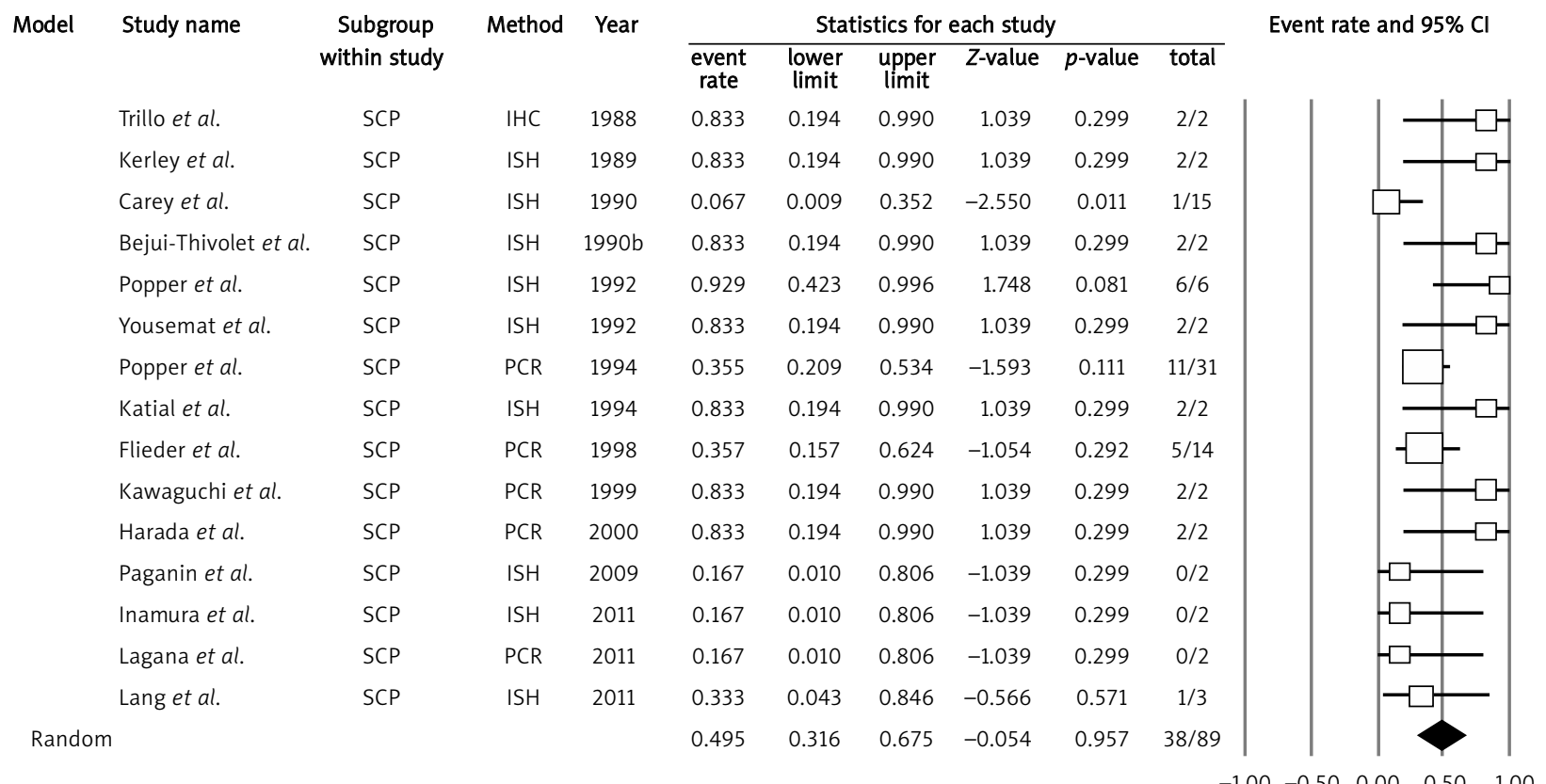

Fig. 1. Forest plot of the 15 studies reporting on HPV detection in bronchial SCPS 
Table 2. Meta-analysis of the 15 studies* stratified by the HPV detection method

\begin{tabular}{|c|c|c|c|c|c|c|c|c|c|c|}
\hline \multirow[t]{2}{*}{$\begin{array}{l}\text { Detection } \\
\text { method }\end{array}$} & \multirow[t]{2}{*}{$\begin{array}{l}\text { No. of } \\
\text { studies }\end{array}$} & \multirow{2}{*}{\multicolumn{2}{|c|}{$\begin{array}{c}\text { Events Sample } \\
\text { size }\end{array}$}} & \multicolumn{2}{|c|}{$\begin{array}{l}\text { Point estimates of } \\
\text { event rates } \\
\text { (fixed effects model) }\end{array}$} & \multicolumn{2}{|c|}{$\begin{array}{c}\text { Point estimates of } \\
\text { event rates } \\
\text { (random effects model) }\end{array}$} & \multirow[t]{2}{*}{ 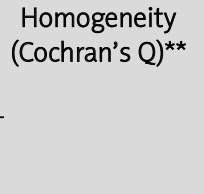 } & \multirow[t]{2}{*}{$\begin{array}{l}\text { I-squared } \\
(12)^{\star \star}\end{array}$} & \multirow[t]{2}{*}{$\begin{array}{l}\text { Homogeneity } \\
(p \text {-value })^{\star \star}\end{array}$} \\
\hline & & & & $\begin{array}{c}\text { Point } \\
\text { estimate }\end{array}$ & $95 \% \mathrm{Cl}$ & $\begin{array}{c}\text { Point } \\
\text { estimate }\end{array}$ & $95 \% \mathrm{Cl}$ & & & \\
\hline $\mathrm{IHC}$ & 1 & 2 & 2 & 0.833 & $0.194-0.990$ & 0.833 & $0.194-0.990$ & 0.000 & 0.000 & 1.000 \\
\hline ISH & 9 & 16 & 36 & 0.478 & $0.268-0.697$ & 0.534 & $0.232-0.812$ & 16.317 & 50.971 & 0.038 \\
\hline PCR & 5 & 20 & 51 & 0.384 & $0.259-0.526$ & 0.391 & $0.252-0.549$ & 4.305 & 7.082 & 0.366 \\
\hline Summary & 15 & 38 & 89 & 0.422 & $0.311-0.542$ & 0.434 & $0.302-0.575$ & 22.690 & 38.300 & 0.065 \\
\hline \multicolumn{4}{|c|}{ Total within (FE) } & & & & & 20.622 & & 0.056 \\
\hline \multicolumn{4}{|c|}{ Total between (FE) } & & & & & 2.069 & & 0.355 \\
\hline \multicolumn{4}{|c|}{ Total between (RE) } & & & & & 2.112 & & 0.348 \\
\hline
\end{tabular}

When stratified by the geographic origin of the study (Table 3), there is significant heterogeneity $(p=0.027)$ only between the studies from Europe, with the percentage of variation up to $63.6 \%$. The highest summary effect size (63.1\%) is derived from studies reported from Other Asia, followed by those conducted in USA/Canada (51.7\%), and Europe (41.1\%). In the between-strata comparisons using the RE model, the difference in results is not significant $(p=0.792)$, indicating that the heterogeneity between the studies from different geographic regions is not statistically significant.

\section{Meta-regression}

In meta-regression testing HPV detection methods as study-level covariates (Table 4), none of the methods resulted in summary point estimates that were significantly different from the reference (IHC), including the effect size difference (0.052) between ISH and PCR methods ( $p=0.626)$. The HPV detection method was not a significant study-level covariate $(p=0.150$ for regression coefficient $\beta 1$ or effect parameter). The same was true when only the studies using ISH $(n=9)$ or PCR $(n=5)$ were included in this meta-regression $(p=0.484)$.

Using Other Asia as the reference, the effect size differences to the other geographic regions are not statistically significant ( $p=0.139$ and $p=0.510$ ) (Table 5). In formal metaregression, the geographic origin of the study did not have a significant impact on the effect size $(p=0.164)$.

\section{Publication bias}

There was little evidence for publication bias among studies based on ISH: Begg $p=0.301$, Egger's $p=0.019$, Duval and Tweedie's trim and fill (RE) method identified no missing studies. For studies using PCR, there was some evidence of publication bias (Begg $p=0.231$; Egger's $p=0.161$ ), but Duval and Tweedie's trim and fill (FE and RE) method imputed 1 hypothetically missing study, with a marginal effect on adjusted point estimates (from 0.391 to 0.373 ).

There was no evidence for publication bias among studies $(n=3)$ from Other Asia and Europe $(n=5)$. For studies

Table 3. Meta-analysis of the 15 studies $^{*}$ stratified by their geographic origin

\begin{tabular}{|c|c|c|c|c|c|c|c|c|c|c|}
\hline \multirow[t]{2}{*}{$\begin{array}{l}\text { Detection } \\
\text { method }\end{array}$} & \multirow[t]{2}{*}{$\begin{array}{l}\text { No. of } \\
\text { studies }\end{array}$} & \multirow{2}{*}{\multicolumn{2}{|c|}{$\begin{array}{c}\text { Events Sample } \\
\text { size }\end{array}$}} & \multicolumn{2}{|c|}{$\begin{array}{l}\text { Point estimates of } \\
\text { event rates } \\
\text { (fixed effects model) }\end{array}$} & \multicolumn{2}{|c|}{$\begin{array}{l}\text { Point estimates of } \\
\text { event rates } \\
\text { (random effects model) }\end{array}$} & \multirow[t]{2}{*}{$\begin{array}{l}\text { Homogeneity } \\
(\text { Cochran's Q) }\end{array}$} & \multirow[t]{2}{*}{$\begin{array}{l}\text { I-squared } \\
\qquad(12)^{\star \star}\end{array}$} & \multirow[t]{2}{*}{$\begin{array}{l}\text { Homogeneity } \\
(p \text {-value })^{\star \star}\end{array}$} \\
\hline & & & & $\begin{array}{l}\text { Point } \\
\text { estimate }\end{array}$ & $95 \% \mathrm{Cl}$ & $\begin{array}{l}\text { Point } \\
\text { estimate }\end{array}$ & $95 \% \mathrm{Cl}$ & & & \\
\hline Other Asia & 3 & 4 & 6 & 0.631 & $0.229-0.908$ & 0.631 & $0.173-0.933$ & 2.878 & 30.510 & 0.237 \\
\hline Europe & 5 & 20 & 56 & 0.356 & $0.226-0.513$ & 0.411 & $0.127-0.770$ & 10.989 & 63.601 & 0.027 \\
\hline North America & a 7 & 14 & 27 & 0.486 & $0.297-0.678$ & 0.517 & $0.297-0.730$ & 6.808 & 11.867 & 0.339 \\
\hline Summary & 15 & 38 & 89 & 0.422 & $0.311-0.542$ & 0.507 & $0.328-0.685$ & 22.690 & 38.300 & 0.065 \\
\hline \multicolumn{4}{|c|}{ Total within (FE) } & & & & & 20.675 & & 0.055 \\
\hline \multicolumn{4}{|c|}{ Total between (FE) } & & & & & 2.015 & & 0.365 \\
\hline \multicolumn{4}{|c|}{ Total between (RE) } & & & & & 0.467 & & 0.792 \\
\hline
\end{tabular}

*All studies reporting only bronchial carcinomas are omitted

$F E$ - fixed effects, $R E$ - random effects 
Table 4. Effect of HPV detection method on the effect size in maximum likelihood meta-regression

\begin{tabular}{|c|c|c|c|c|c|}
\hline \multirow{2}{*}{$\begin{array}{l}\text { Study-level covariates } \\
\text { HPV detection method }\end{array}$} & \multirow{2}{*}{$\begin{array}{l}\text { No. of studies } \\
\text { (homogeneity } p \text {-value) }^{\star \star}\end{array}$} & \multicolumn{2}{|c|}{ Effect size* } & \multicolumn{2}{|c|}{ Difference in effect size estimates } \\
\hline & & Point estimate & $95 \% \mathrm{Cl}$ & $\begin{array}{c}\text { Difference in } \\
\text { point estimates }\end{array}$ & $95 \% \mathrm{Cl}$ \\
\hline $\mathrm{IHC}$ & $1(p=1.000)$ & 0.833 & $0.194-0.990$ & 1.000 & \\
\hline ISH & $9(p=0.038)$ & 0.534 & $0.232-0.812$ & $0.555^{1}$ & $0.393-0.717$ \\
\hline PCR & $5(p=0.366)$ & 0.391 & $0.252-0.549$ & $0.607^{2}$ & $0.473-0.741$ \\
\hline \multicolumn{6}{|c|}{ Meta-regression for all methods Slope: $-0.409(95 \% \mathrm{Cl}:-0.968-0.148)(p=0.150)$ : Intercept: $2.389(95 \% \mathrm{Cl}:-1.327-6.107)(p=0.207)$} \\
\hline ISH & $9(p=0.038)$ & 0.534 & $0.232-0.812$ & 1.000 & \\
\hline PCR & $5(p=0.366)$ & 0.391 & $0.252-0.549$ & $0.052^{3}$ & $-0.158-0.262$ \\
\hline Meta-regression (ISH/PCR) & Slope: -0.386 (95\% & $1.469-0.697)(p$ & 484): Interce & $95 \% \mathrm{Cl}:-5.062-9$. & 525) $(p=0.548)$ \\
\hline \multicolumn{6}{|c|}{$\begin{array}{l}\text { *Random effects model } \\
{ }^{* *} \text { Cochran's } Q ; I H C \text {, immunohistochemistry } \\
{ }^{{ }^{1} p=0.126} \\
{ }^{2} p=0.087 \\
{ }^{3} p=0.626 \\
\left.\text { ISH - in situ hybridization, } P C R \text { - polymerase chain reaction, Slope; effect parameter (= regression coefficient } \beta_{1}\right) \text {, Intercept }\left(=\operatorname{coefficient} \beta_{0}\right)\end{array}$} \\
\hline
\end{tabular}

Table 5. Effect of geographic origin of the study on the effect size in maximum likelihood meta-regression

\begin{tabular}{lccccc} 
Study-level covariates & No. of studies & \multicolumn{2}{c}{ Effect size* $_{\text {Geographic Origin of Study }}$} & \multicolumn{2}{c}{ Difference in effect size estimates } \\
\cline { 3 - 6 } & (homogeneity $p$-value) ${ }^{* *}$ & Point estimate & $95 \% \mathrm{Cl}$ & $\begin{array}{c}\text { Difference in } \\
\text { point estimates }\end{array}$ \\
\hline Other Asia & $3(p=0.237)$ & 0.631 & $0.173-0.933$ & 1.000 & $0.321-0.604$ \\
\hline Europe & $5(p=0.027)$ & 0.411 & $0.127-0.770$ & 0.3091 & $-0.088-0.707$ \\
\hline North America & $7(p=0.339)$ & 0.517 & $0.297-0.730$ & $0.148^{2}$ & $-0.273-0.569$
\end{tabular}

*Random effects model

${ }^{* *}$ Cochran's $Q$

${ }^{1} p=0.139$

${ }^{2} p=0.510$

Slope; effect parameter (= regression coefficient $\beta_{1}$ ), Intercept (= coefficient $\beta_{0}$ )

$(n=7)$ from North America, there was some evidence for publication bias (Begg $p=0.088$; Egger's $p=0.0691$ ), and Duval and Tweedie's trim and fill (FE and RE) method imputed 2 hypothetically missing studies, with a marginal effect on adjusted point estimates (from 0.517 to 0.441 ).

\section{Sensitivity analysis}

Meta-analytic results seemed relatively robust to all $(n=14)$ one-by-one study removals, with little change in the magnitude and precision of the FE and RE summary point estimates of the effect size. The single most influential study was the one with the highest sample size $(n=31)$ [98], the removal of which would increase the summary effect size from 0.422 to 0.475 (FE model) and from 0.495 to 0.538 (RE model).

\section{Discussion}

The role of HPV in etiology of bronchial papillomas has received increasing interest since the late 1970s, when the first evidence was provided [79-82]. The accumulated literature has been reviewed most recently some 10 years ago $[8,84]$, but no formal meta-analysis has been published as yet. The formal meta-analysis presented in this communication covers all the published literature reporting HPV detection in bronchial SCPS ( $n=15$ studies), and also updates the author's own review of 2002 [84]. Importantly, the authors did not make any restrictions as to the HPV detection methods, although some of the early HPV detection techniques (IHC) are obsolete by now. This was just to validate by formal meta-analysis and meta-regression the frequently presented concept that the wide variation in HPV prevalence in bronchial SCPS might be explained by different detection techniques [8,84]. The other study-level covariate addressed in this meta-analysis and meta-regression is the geographic origin of the study, also listed among potential causes of variation in HPV prevalence in respiratory tract neoplasia [84-86].

To evaluate the heterogeneity in meta-analysis is crucial because the presence or absence of true heterogeneity (i.e., between-study variability) directly affects the statistical model that should be used to analyze the database [87, 104-106]. The usual way of assessing whether true heterogeneity exists has been the Q test, originally introduced by Cochran (1954) [107]. Significant $p$-values in the Q test implicate true heterogeneity and warrant the use of a random effects (RE) model to test both within- and between-study variability. The Q statistic does not indicate the magnitude of true heterogeneity, however, but only its statistical significance [107]. On the other hand, the $\mathrm{I}^{2}$ index, introduced by Higgins et al. (2003), measures the extent of true heterogeneity, expressed 
as the percentage of the total between-study variability in the effect sizes [108]. One of the major advantages of the $\mathrm{I}^{2}$ index is that the indices obtained from meta-analyses with different numbers of studies and different effect metrics are directly comparable $[104,108]$.

Given the above considerations, there is little doubt that marked heterogeneity exists only between the studies $(n=9)$ using ISH, but not those using PCR $(n=5)$ methods, as estimated using the Q test and $\mathrm{I}^{2}$ index (Table 2). This marked heterogeneity among studies comprising the bulk (9/15) of all included studies justifies the adoption of the RE model to analyze the summary statistics for heterogeneity [104-106]. Using the RE model, the most important conclusion implies that there is no true heterogeneity between the studies using different HPV detection techniques, as indicated by the nonsignificant homogeneity $p$-value $(p=0.348)$ for the betweenstudy comparison, also when the FE model is used ( $p=0.355)$. In other words, we can revisit the concept raised in some recent reviews $[8,84]$, suggesting that the differences in HPV prevalence reported in bronchial papillomas might be explained by the different HPV detection techniques. This statement is limited, however, by the relatively small number of studies reporting on HPV detection in these lesions.

An alternative view suggests that this variable HPV prevalence would be related to the different geographic regions of the study origin $[8,84]$. To evaluate this concept, we performed our meta-analyses stratified by the geographic origin of studies (Table 3 ). Both the $\mathrm{Q}$ test and the $\mathrm{I}^{2}$ index demonstrate a statistically significant heterogeneity ( $p=$ $\left.=0.027, \mathrm{I}^{2}=63.6 \%\right)$ only between the studies $(n=5)$ derived from Europe, but not among those from the other two geographic regions (Other Asia, North America). However, when the RE model was used to calculate the summary statistics, the homogeneity $p$-value was 0.792 for the between-strata comparison. This implies that the seemingly wide variation (11.8-63.6\%) in HPV prevalence from different geographic regions is not significant according to the strict meta-analytical criteria. Noteworthy, however, is that the highest summary effect size estimates (63.1\% for Other Asia) are based on a small number $(n=3)$ of studies only, while the lower estimates (41.1-51.7\%) are derived from at least 5 to 7 studies (Table 3). In this respect, we should also keep in mind one of the shortcomings of the $\mathrm{Q}$ statistic, i.e., it has a poor power to detect true heterogeneity in a meta-analysis including a small number of studies, but excessive power to detect even insignificant variability when a large number of studies is included [87, 104-108].

We also performed meta-regression to formally compare these differences in summary effect sizes [92]. In meta-regression with the HPV detection method as the covariate, the regression coefficient for the effect parameter ( $\beta 1$, or slope) was not statistically significant $(p=0.150)$. The same is true when the geographic origin of the study $(p=0.164)$ was tested for its impact as the study-level covariate. These data formally confirm that HPV detection method and geographic origin of the study are not significant study-level covariates accounting for the heterogeneity of HPV prevalence in bronchial papilloma studies. The results of meta-regression did not change if only the studies based on ISH and PCR were included in the analysis. Thus, despite the seemingly higher summary HPV prevalence derived from ISH studies (53.4\%) as compared with the PCR studies (39.1\%), this difference does not reach statistical significance $(p=0.484)$.

Some evidence for publication bias was detected, but this usually had an insignificant effect on the adjusted point estimates in stratified meta-analysis. There was no evidence for publication bias among ISH-based studies, and the slight publication bias revealed among the PCR studies resulted only in a negligible drop of the point estimates (from 39.1\% to $37.3 \%$ ). As to the geographic areas, some publication bias was evidenced only among the studies from North America. Thus, for this region, Duval and Tweedie's trim and fill (both FE and RE) method imputed 2 hypothetically missing studies, with a marginal impact on summary point estimates (51.7\% to $44.1 \%)$. Thus, it remains to be seen whether the future studies from this region will report somewhat lower HPV prevalence than the summary effect size (51.7\%) derived from the currently available studies.

In sensitivity analysis, based on one-by-one removal of all 15 studies, all meta-analytic results seemed relatively robust to all removals, with no major change in the magnitude or precision of either the FE or RE summary point estimates of the effect size (Fig. 1). In a meta-analysis based on such a small number of studies, and relatively small number of analyzed cases ( $n=89$ ), however, it is expected that the most influential studies are those based on the largest number of cases, and/or those with very low or very high event rates. In this analysis, such a single study was that by Popper et al. [98], reporting HPV prevalence of $35.5 \%$ (11/31) in a series of 31 bronchial SCPs. The relative (fixed) weight of this single study is 42.9, and even if reporting an effect size (0.355) far below the summary effect size (0.495) derived from all studies, removal of this study from the meta-analysis would increase the summary effect size (random) only from 0.495 to 0.538 , i.e., by $4.3 \%$. To be truly influential, any such hypothetical study should include over a hundred cases and demonstrate HPV prevalence markedly deviating (down- or upwards) from the summary effect size derived from the existing 15 studies.

Taken together, these meta-analytical results based on all published literature ( $n=15$ eligible studies) on HPV detection in bronchial squamous cell papillomas imply that HPV prevalence varies according to i) HPV detection method, and ii) geographic origin of the study. In stratified meta-analysis and meta-regression, however, this variability is not significantly associated with either of these two study-level covariates. Because not formally confirmed by the metaregression, it seems premature to conclude that bronchial papillomas in different geographic regions have a different etiology, as hypothesized in some recent studies for bronchial cancer [109]. Large multi-center studies based on larger series, as well as prospective cohort studies, are needed to better elucidate the impact of HPV in pathogenesis of bronchial papillomas (papillomatosis), which are a not infrequent accompaniment of their (synchronous or metachronous) malignant counterparts, i.e., bronchial squamous cell carcinoma $[2,8,11,27,39,40,50,51,57,58,66,71,84]$.

The authors declare no conflict of interests. 


\section{References}

1. Ashmore PG. Papilloma of the bronchus: case report. J Thorac Surg 1954; 27: 293-4.

2. McCart H. Tracheal and bronchial papillomatous implant showing malignant changes. Ann Otol Rhinol Laryngol 1954; 63: 498-9.

3. Minetto E, Garbagni R. Bronchial papilloma. Ann Otolaryngol 1954; 71: 642-9.

4. Schaff B, Thomson RV. Papillomatosis of the trachea and bronchi. Am Rev Tuberc 1955; 71: 429-36.

5. Drennan JM, Douglas AC. Solitary papilloma of a bronchus. J Clin Pathol 1965; 18: 401-2.

6. Jackson DA, Hatch HB. Solitary benign squamous papilloma of the bronchus. Report of two cases. Am Rev Respir Dis 1968; 97: 699-705.

7. Maxwell RJ, Gibbons JR, O'Hara MD. Solitary squamous papilloma of the bronchus. Thorax 1985; 40: 68-71.

8. Syrjänen K. HPV infections in the respiratory tract. In: Syrjänen K, Syrjänen S (eds.). Papillomavirus infections in human pathology. J Wiley \& Sons, New York 2000; 355-78.

9. Gardiol D. Isolated bronchial papilloma in the adult. Anatomicalclinical study of three cases. Oncologia 1959; 12: 304-16.

10. Elliott GB, Belkin A, Donald WA. Cystic bronchial papillomatosis. Clin Symp 1962; 13: 62-7.

11. Smith JF, Dexter D. Papillary neoplasms of the bronchus or low-grade malignancy. Thorax 1963; 18: 340-9.

12. Laubscher FA. Solitary squamous cell papilloma of bronchial origin. Am J Clin Pathol 1969; 52: 599-603.

13. Spencer H, Dail DH, Arneaud J. Non-invasive bronchial epithelial papillary tumors. Cancer 1980; 45: 1486-97.

14. Strupler W. Tracheo-bronchial papillomatosis. Pract Otorhinolaryngol (Basel) 1955; 17: 391-7.

15. Fojanini G, Novi I. Solitary bronchial papilloma. Arch Ital Chir 1957; 82: 353-63.

16. Sochocky S. Papilloma of the bronchus. Am Rev Tuberc 1958; 78: 916-20.

17. Shinton NK. The histlogical classification of lower repiratory tract tumours. Br J Cancer 1963; 17: 213-21.

18. Melillo G. Benign tumors of the tracheo-bronchial tree. Arch Tisiol Mal Appar Respir 1966; 21: 464-73.

19. Pletnev SD. Bronchial papillomas. Vopr Onkol 1967; 13: 72-8.

20. Crinquette J, Saout J, Bouchez J. Apropos of an unusual form of benign tumor of the bronchus. J Sci Med Lille 1968; 86: 19-24.

21. Gardiol D. Bronchial papilloma of the epidermoid type. Nosology and diagnosis through biopsy. Schweiz Med Wochenschr 1968; 98: 1902-6.

22. Sukovatykh LS, Golubovich IA, Sapun AS. Papilloma of the bronchus. Vopr Onkol 1968; 14: 108-9.

23. Crinquette J, Saout J, Delacroix R, Bouchez J. Case of solitary papilloma of the bronchus. Bronches 1969; 19: 203-8.

24. Gardiol D. Biopsy diagnosis of bronchial papilloma with epidermoid form in adults. Ann Otolaryngol Chir Cervicofac 1969; 86: 337-8.

25. Miller DR. Benign tumors of lung and tracheobronchial tree. Ann Thorac Surg 1969; 8: 542-60.

26. Maksimov IA, Pletnev SD, Shevelev VI. Bronchial surgery in endobronchial benign tumors. Khirurgiia (Mosk) 1970; 46: 28-32.

27. Paltrinieri E, Zappala G. Solitary bronchogenic papilloma with fatal clinical evolution. Arch De Vecchi Anat Patol 1970; 56: 641-50.

28. Dybicki J, Zmarzlik Z, Dabrowski J, Tokarczyk T. Isolated papillomas of the bronchus. Gruzlica 1971; 39: 409-15.

29. Freant LJ, Sawyers JL. Benign bronchial polyps and papillomas. Ann Thorac Surg 1971; 11: 460-67.

30. Mariani B, Bisetti A, Velluti G, Brocchi G, Pastorelli S. Bronchial papilloma and papillomatosis. Anatomoclinical contribution. Bronches 1971; 21: 327-48.

31. Dybicki J, Zmarzlik Z, Dabrowski J, Tokarczyk T. Isolated bronchial papillomas. Pol Med J 1972; 11: 380-7.

32. Kucharski H, Leonhard B. Case of multiple bronchial papilloma in an adult woman. Wiad Lek 1972; 25: 1563-5.

33. Cafiero F, Cogo L, Italia R, Berni F, Pezzoli C, Felletti V. 8 cases of benign bronchopulmonary tumors. Minerva Med 1973; 64: 3103-17.

34. Milosevic D. Papilloma with tracheo-bronchial localization in adults. Plucne Bolesti Tuberk 1974; 26: 221-5.
35. Aliperta A, Bellissimo U, Bocchino M, Perna A. Benign tumors of the trachea and bronchi. Bronches 1975; 25: 333-42.

36. Grigor'eva SP, Revzis MG. Rare benign tumors of the lungs. Vopr Onkol 1975; 21: 17-28.

37. Steinmann EP. Solitary bronchial papilloma (author's transl). HNO 1975; 23: 213-5.

38. Marino C, Romagnoli E, Todaro F, Meli E. Endobronchial benign tumors. Arch De Vecchi Anat Patol 1977; 62: 563-9.

39. Blinov NN, Kolosov AE. Morphology and clinical aspects of malignant bronchial papillomas. Vopr Onkol 1978; 24: 96-8.

40. DiMarco AF, Montenegro H, Payne CB Jr., Kwon KH. Papillomas of the tracheobronchial tree with malignant degeneration. Chest 1978; 74: 464-5.

41. Dornetzhuber V, Dobrota S. Two rare forms of bronchial papilloma (author's transl). Bratisl Lek Listy 1978; 70: 713-9.

42. Memon AM, Ramisetti DK, Ayvazian LF. Mobile bronchial papilloma spontaneously expectorated. J Med Soc N J 1978; 75: 409-11.

43. Minnigerode B, Okulicz G. Clinical pattern of bronchial papilloma. Otolaryngol Pol 1978; 32: 173-9.

44. Witz JP, Roeslin N, Avalos S, Morand G, Wihlm JM. Benign tracheobronchial tumors. Other tumors. Ann Chir 1979; 33: 541-4.

45. Zimmermann A, Lang HR, Muhlberger F, Bachmann M. Papilloma of the bronchus. Respiration 1980; 39: 286-90.

46. Zivkov A, Mincev K. Papilloma bronchi (author's transl). Plucne Bolesti Tuberk 1980; 32: 47-9.

47. lijima T, Hatakeyama N, Yanagimachi Y, Hirano T, Heishiki A, Matsuzawa T. A case of pulmonary papillomatosis (author's transl). Rinsho Hoshasen 1981; 26: 965-8.

48. Weingarten J. Cytologic and histologic findings in a case of tracheobronchial papillomatosis. Acta Cytol 1981; 25: 167-70.

49. Xu LT, Sun ZF, Li ZJ, Wu LH, Wang ZZ. Tracheobronchial tumors: an eighteen-year series from Capital Hospital, Peking, China. Ann Thorac Surg 1983; 35: 590-6.

50. Roviaro GC, Varoli F, Pagnini CA. Is the solitary papilloma of the bronchus always a benign tumor? ORL J Otorhinolaryngol Relat Spec 1981; 43: 301-8.

51. Rahman A, Ziment I. Tracheobronchial papillomatosis with malignant transformation. Arch Intern Med 1983; 143: 577-8.

52. Sun CF, Xu LT, Le ZJ. Benign endotracheobronchial tumors: report of 14 cases. Zhonghua Wai Ke Za Zhi 1985; 23: 537-8.

53. Hurt R. Benign tumours of the bronchus and trachea, 1951-1981. Ann R Coll Surg Engl 1984; 66: 22-6.

54. Barzo P, Molnar L, Minik K. Bronchial papillomas of various origin. Orv Hetil 1986; 127: 2069-72.

55. Niimi T, Imaizumi M, Kamiya I, Abe T, Nagura H. Immunohistochemical study of a case of solitary benign squamous cell papilloma of the bronchus. Nihon Kyobu Shikkan Gakkai Zasshi 1987; 25: 681-5.

56. Aota M, Nakayama S, Jinno K, Daitoh N, Katsura H, Wada H. A case of solitary bronchial papilloma and a review of the literature. Nippon Kyobu Geka Gakkai Zasshi 1988; 36: 1194-9.

57. Katsura K, Sugiyama K, Kitamura H, Uwabe Y, Matsuoka T, Nagata N. A case of squamous cell carcinoma of the lung associated with acanthosis nigricans and solitary bronchial papilloma. Nihon Kyobu Shikkan Gakkai Zasshi 1992; 30: 1991-5.

58. Bejui-Thivolet F, Chardonnet Y, Patricot LM. Human papillomavirus type 11 DNA in papillary squamous cell lung carcinoma. Virchows Arch A Pathol Anat Histopathol 1990; 417: 457-61.

59. Kaneda M, Sakai T, Hayashi T, Hiraiwa T, Ohomoto Y, Shiroyama K. A case of solitary bronchial papilloma with elevated serum CEA concentration. Kyobu Geka 1990; 43: 419-22.

60. Lee CM, Lin YN. Solitary squamous papilloma of the bronchus: report of a case. J Formos Med Assoc 1990; 89: 63-5.

61. Abdullah AK, Danial BH, Zeid A, Chaikhouni A, Ejeckam GC. Solitary bronchial papilloma presenting with recurrent dyspnea attacks: case report with computed tomography findings. Respiration 1991; 58: $62-4$.

62. Ohno N, Hashihira M, Miyamoto Y, Katsura H. A case of solitary bronchial papilloma and a review of the literature. Nihon Kyobu Shikkan Gakkai Zasshi 1991; 29: 618-21.

63. Ren H, Bai G, Li Z, Zhang Z, Sun C, Xu L. A clinical analysis of 38 patients with primary tracheo bronchial tumors. Chin Med Sci J 1994; 9: 263-5. 
64. Sokur PP. The excision of a benign tumor of the bronchus during bronchoscopy. Klin Khir 1997; 5: 27-9.

65. Sekine I, Kodama T, Yokose T, Nishiwaki Y, Suzuki K, Goto K. Rare pulmonary tumors - a review of 32 cases. Oncology 1998; 55: 431-4.

66. Inoue Y, Oka M, Ishii H, Kimino K, Kishikawa M, Ito M. A solitary bronchial papilloma with malignant changes. Intern Med 2001; 40: 56-60.

67. Barzo P. Benign tracheal and bronchial tumors - from the viewpoint of the bronchologist. Orv Hetil 2002; 143: 1607-8.

68. McNamee CJ, Lien D, Puttagunta L, Conlan AA. Solitary squamous papillomas of the bronchus: a case report and literature review. J Thorac Cardiovasc Surg 2003; 126: 861-3.

69. Lee YO, Kim DH, Kim CH, Park TI, Cho S. Rare tumor of the tracheobronchial tree: solitary squamous papilloma. Thorac Cardiovasc Surg 2009; 57: 178-9.

70. Paganin F, Prevot M, Noel JB, Frejeville M, Arvin-Berod C, Bourdin A A solitary bronchial papilloma with unusual endoscopic presentation: case study and literature review. BMC Pulm Med 2009; 9 : 40-4.

71. Urushiyama H, Yamauchi Y, Suzuki S, et al. Case of sarcoidosis with squamous cell carcinoma which originated from solitary bronchial papilloma. Nihon Kokyuki Gakkai Zasshi 2010; 48: 815-20.

72. Kadota K, Haba R, Katsuki N, Hayashi T, Miyai Y, Bando K. Cytolog ical findings of mixed squamous cell and glandular papilloma in the lung. Diagn Cytopathol 2010; 38: 913-7.

73. Kim SR, Park JK, Park SJ, et al. Solitary bronchial squamous papilloma presenting as a plaque-like lesion in a subject with asthma. Am J Respir Crit Care Med 2011; 183: 555-6.

74. Lang TU, Khalbuss WE, Monaco SE, Pantanowitz L. Solitary Tracheobronchial Papilloma: Cytomorphology and ancillary studies with histologic correlation. Cytojournal 2011; 8: 6.

75. Aissa I, Darouaz S, Ayadi A, El MF, Kilani T, Ghedira H. Squamous endobronchial papillomatosis. Tunis Med 2012; 90: 83-4.

76. Syrjänen KJ, Pyrhönen S, Syrjänen SM. Evidence suggesting human papillomavirus (HPV) etiology for the squamous cell papilloma of the paranasal sinus. Arch Geschwulstforsch 1983; 53: 77-82.

77. Syrjänen S, Happonen RP, Virolainen E, Siivonen L, Syrjänen K. Detection of human papillomavirus (HPV) structural antigens and DNA types in inverted papillomas and squamous cell carcinomas of the nasal cavities and paranasal sinuses. Acta Otolaryngol (Stockh) 1987; 104: 334-41.

78. Syrjänen KJ. HPV infections in benign and malignant sinonasal lesions. J Clin Pathol 2003; 56: 174-81.

79. Roglic M, Jukic S, Damjanov I. Cytology of the solitary papilloma of the bronchus. Acta Cytol 1975; 19: 11-3.

80. Rubel L, Reynolds RE. Cytologic description of squamous cell papilloma of the respiratory tract. Acta Cytol 1979; 23: 227-31.

81. Syrjänen KJ. Condylomatous changes in neoplastic bronchial epithelium. Report of a case. Respiration 1979; 38: 299-304.

82. Syrjänen KJ. Epithelial lesions suggestive of a condylomatous origin found closely associated with invasive bronchial squamous cell carcinomas. Respiration 1980; 40: 150-60.

83. Trillo A, Guha A. Solitary condylomatous papilloma of the bronchus. Arch Pathol Lab Med 1988; 112: 731-3.

84. Syrjänen KJ. HPV infections and lung cancer. J Clin Pathol 2002; 55 : 885-91.

85. Syrjänen KJ. Annual disease burden due to human papillomavirus (HPV) 6 and 11 infections in Finland. Scand J Infect Dis 2009; Suppl 107: 3-32.

86. Syriänen KJ. Annual disease burden due to human papillomavirus (HPV) 16 and 18 infections in Finland. Scand J Infect Dis 1009; Suppl 108: 2-32.

87. Hardy RJ, Thompson SG. Detecting and describing heterogeneity in meta-analysis. Stat Med 1998; 17: 841-56.

88. Sterne JA, Gavaghan D, Egger M. Publication and related bias in metaanalysis: power of statistical tests and prevalence in the literature. J Clin Epidemiol 2000; 53: 1119-29.

89. Begg CB, Mazumdar M. Operating characteristics of a rank corre lation test for publication bias. Biometrics 1994; 50: 1088-101.

90. Egger M, Davey SG, Schneider M, Minder C. Bias in meta-analysis detected by a simple, graphical test. BMJ 1997; 315: 629-34.
91. Duval S, Tweedie R. Trim and fill: a simple funnel-plot-based method of testing and adjusting for publication bias in meta-analysis. Biometrics 2000; 56: 455-63.

92. Thompson SG, Sharp SJ. Explaining heterogeneity in meta-analysis: a comparison of methods. Stat Med 1999; 18: 2693-708.

93. Kerley SW, Buchon-Zalles C, Moran J, Fishback JL. Chronic cavitary respiratory papillomatosis. Arch Pathol Lab Med 1989; 113: 1166-9.

94. Carey FA, Salter DM, Kerr KM, Lamb D. An investigation into the role of human papillomavirus in endobronchial papillary squamous tumours. Respir Med 1990; 84: 445-7.

95. Popper HH, Wirnsberger G, Juttner-Smolle FM, Pongratz MG Sommersgutter $M$. The predictive value of human papilloma virus (HPV) typing in the prognosis of bronchial squamous cell papillomas. Histopathology 1992; 21: 323-30.

96. Yousem SA, Ohori NP, Sonmez-Alpan E. Occurrence of human papillomavirus DNA in primary lung neoplasms. Cancer 1992; 69: 693-7.

97. Katial RK, Ranlett R, Whitlock WL. Human papilloma virus associated with solitary squamous papilloma complicated by bronchiectasis and bronchial stenosis. Chest 1994; 106: 1887-9.

98. Popper HH, el-Shabrawi Y, Wockel W, Hofler G, Kenner L, JuttnerSmolle FM. Prognostic importance of human papilloma virus typ ing in squamous cell papilloma of the bronchus: comparison of in situ hybridization and the polymerase chain reaction. Hum Pathol 1994; 25: 1191-7.

99. Flieder DB, Koss MN, Nicholson A, Sesterhenn IA, Petras RE, Travis WD. Solitary pulmonary papillomas in adults: a clinicopathologic and in situ hybridization study of 14 cases combined with 27 cases in the literature. Am J Surg Pathol 1998; 22: 1328-42.

100. Kawaguchi T, Matumura A, luchi K, et al. Solitary squamous papilloma of the bronchus associated with human papilloma virus type 11. Intern Med 1999; 38: 817-9.

101. Harada H, Miura K, Tsutsui Y, Mineta H, Urano M, Abe M. Solitary squamous cell papilloma of the lung in a 40-year-old woman with recurrent laryngeal papillomatosis. Pathol Int 2000; 50: 431-9.

102. Inamura K, Kumasaka T, Furuta R, Shimada K, Hiyama N, Furuhata Y. Mixed squamous cell and glandular papilloma of the lung: a case study and literature review. Pathol Int 2011; 61: 252-8.

103. Lagana SM, Hanna RF, Borczuk AC. Pleomorphic (spindle and squamous cell) carcinoma arising in a peripheral mixed squamous and glandular papilloma in a 70-year-old man. Arch Pathol Lab Med 2011; 135: 1353-6.

104. Huedo-Medina T, Sanchez-Meca J, Marin-Martinez F, Botella J. Assessing heterogeneity in meta-analysis: Q statistic or 12 index? CHIP Documents. 2006; Paper 19. Available at: http://digitalcommons. uconn.edu/chip_docs/19.

105. Field AP. Meta-analysis of correlation coefficients: A Monte Carlo comparison of fixed- and random-effects methods. Psychol Meth 2001; 6: 161-80.

106. Field AP. The problems in using fixed-effects models of meta-analysis on real-world data. Understand Stat 2003; 2: 77-96.

107. Cochran WG. The combination of estimates from different experiments. Biometrics 1954; 10: 101-29.

108. Higgins JPT, Thompson SG, Deeks JJ, Altman DG. Measuring inconsistency in meta-analyses. Brit Med J 2003; 327: 557-60.

109. Syrjänen K, Silvoniemi M, Salminen E, Vasankari T, Syrjänen S. Detection of human papillomavirus genotypes in bronchial cancer using sensitive multimetrix assay. Anticancer Res 2012; 32: 625-31.

\section{Address for correspondence}

Prof. Kari Syrjänen MD, PhD, FIAC

Department of Oncology \& Radiotherapy

Turku University Hospital

Savitehtaankatu 1

FIN-20521 Turku, Finland

tel. $+358-2-3131834$

fax $+358-2-3132809$

e-mail: kari.syrjanen@tyks.fi

Submitted: 18.12.2012

Accepted: 16.07 .2013 